\title{
Tools for Assessing Sustainable Development of Territories Taking into Account Cluster Effects
}

\author{
Irina S. Ferova, Elena V. Lobkova, \\ Ekaterina N. Tanenkova and Svetlana A. Kozlova* \\ Siberian Federal University \\ 79 Svobodny, Krasnoyarsk, 660041, Russia
}

Received 25.02.2019, received in revised form 01.04.2019, accepted 09.04.2019

Challenges and search for sustainable ways of territories' development cause serious concern to authorities around the globe. The choice of methodological approaches for assessment and monitoring, indicators for sustainability criteria, as well as the ways of their processing are an important conceptual basis that provides effective facilitation of the administered territories development.

The study is aimed at finding and analyzing the existing approaches and tools for territorial development monitoring, as well as elaboration of methodological and procedural framework for assessing the territories sustainability to solve social and economic problems. Herewith, in the authors' opinion, the main conceptual and methodological prerequisite that distinguishes the proposed approach, should take into account the effects of interregional and intersectoral interaction or, in other words, the effects of cluster transfers. It has been revealed that there is still no consensus among the scientific works' authors not only concerning theoretical aspects, but also on methodological issues of the monitoring procedure and tools for assessing the development sustainability, especially in the context of cluster approach.

The analysis of the main methodological approaches to assessing the sustainable development of various levels systems (national and regional economies, territories, industries, enterprises and products) is given in the paper. Systematization of the approaches and tools used by scientists from different countries, as well as international organizations and institutions, has been carried out. Advantages, disadvantages and limitations for the practical application of the selected methodological approaches are indicated. The essence of the TOPSIS method as a tool for assessing the sustainability of the territories' development, taking into account the multiplicative effects of interregional and intersectoral interaction is given. It has been shown that it is the cluster approach that acts as an effective tool for managing the sustainable development of territorial systems.

Keywords: sustainable development, territory, cluster approach, the TOPSIS method, monitoring, social and economic challenges, assessment tools.

(C) Siberian Federal University. All rights reserved

* Corresponding author E-mail address: iferova@yandex.ru

ORCID: 0000-0002-3389-7822 (Ferova)\$ 0000-0003-0858-201X (Kozlova)

This work is licensed under a Creative Commons Attribution-NonCommercial 4.0 International License (CC BY-NC 4.0). 
The article was prepared within the framework of the interdisciplinary basic research scientific projects competition, carried out by the Russian Foundation for Basic Research and the Government of Krasnoyarsk Krai in 2018, project No. 18-410-242005 p_.мк "Elaboration of Methodology for the Sustainable Development of the Krasnoyarsk Krai Territories”.

Research area: economics.

Citation: Ferova, I.S., Lobkova, E.V., Tanenkova E.N., Kozlova, S.A. (2019). Tools for assessing sustainable development of territories taking into account cluster effects. J. Sib. Fed. Univ. Humanit. soc. sci., 12(4), 600-626. DOI: 10.17516/1997-1370-0412.

\section{Introduction}

The concept of sustainable development was first introduced in the report "Our Common Future" by the World Commission on Environment and Development in 1987. According to the concept, sustainable development is development that meets the needs of the present without compromising the ability of future generations to meet their own needs (World Commission on Environment..., 1987). The United Nations Development Summit held in September 2015 formally adopted the agreement "Transforming Our World: the 2030 Agenda for Sustainable Development", covering three aspects of economic, social and environmental sustainability aimed at ending poverty globally and ensuring decent life for all people.

The UN has currently formulated 17 sustainable development goals: no poverty; zero hunger; good health and well-being; quality education; gender equality; clean water and sanitation; affordable and clean energy; decent work and economic growth; industry, innovation and infrastructure; reduced inequalities; sustainable cities and communities; responsible consumption and production; climate action; life below water; life on land; peace, justice and strong institutions and partnerships for the goals. In this way, the versatility and importance of this issue imposes special requirements for assessment, monitoring and management tools.

The traditional approach to the choice for the tools to assess sustainability is formation of a list of indicators (both statistical and expert ones), converting them to the type required for assessing and calculating an aggregate sustainability index. The results of this procedure are used to develop recommendations to the administrative bodies of a facility (territory) and to conduct a comparative assessment of the development and sustainability level of different countries, regions, cities, etc. There are three aspects of sustainability: economic, social and environmental. Each of them may include additional assessment areas or aspects at the author' discretion. A review of various approaches and tools for assessing the territories sustainability 
used in the global practice demonstrated that the main difficulty in developing methods and approaches is the selection of tools for summarizing (aggregating) data, bringing them to a unified measurement system, choosing coefficients of indicators significance (importance) and their assessment, as well as the dynamic nature of the environment where the facilities under study function, and the need to take into account the interaction effects.

\section{Scientific literature review}

A significant contribution into the development of indicators and tools system for the territories sustainability assessment was made by international and regional organizations:

- Driving Force - State - Response (DSR) model developed by the United Nations Commission on Sustainable Development (UNCSD) (Commission on Sustainable Development, 2001);

- Pressure - State - Response (PSR) model of the Organization for Economic Cooperation and Development (OCED) (Organization for Economic Co-Operation and Development, 2001);

- Society - Economy - Environment model proposed by the United Nations Environment Program (UNEP) (Global Reporting Initiative, 2002);

- Expanding the Measure of Wealth: Indicators of Environmentally Sustainable Development model developed by the World Bank (Bhada, Hoornweg, 2009).

The index systems of the international organizations focus on forming theoretical foundations of sustainable development, recognizing the environmental aspect as a dominant one in their concepts. There is also a significant number of national studies.

The European Union member states consider the following aspects of sustainability: socio-economic (real GDP per capita), sustainable consumption and production, social inclusion (poverty level and social exclusion), demographic changes (employment rate of elderly people), public health (life expectancy), climate change and energy consumption (greenhouse gas emissions, primary energy consumption), sustainable transport (energy consumption of transport relative to GDP), natural resources, global partnership and good governance (Sustainable Development..., 2015).

The following sustainable development indicators, structured by groups, were developed in the UK:

1) overall progress and development priorities assessment (basic statistical indicators of socio-economic development); 
2) sustainable economy (indicators of efficient use of resources; economic stability and competitiveness of the national economy; development of personnels' professional skills, sustainable production and consumption);

3) building a sustainable society (employment promotion; healthcare development; travel opportunities expansion; development of favorable environment; effective management institutions);

4) environment and resource management (climate change and energy conservation; air and atmosphere, fresh water, seas, oceans and coasts, wildlife indicators);

5) international cooperation and development (Department of the Environmen..., 1996).

In 2006 the Ministry of the Environment and Water Resources of Singapore developed the Green Plan, which includes the following key indicators for sustainable development of the country: air quality, manage emissions from stationary source, manage emissions from mobile sources, climate change, energy efficiency indicators, energy management practices of businesses, use of cleaner energy (such as natural gas) and renewable energy (such as solar and biomass) indicators (Chua, 2006).

To assess sustainability China uses index systems, which include the following components: investments, innovative economy and industrial renewal, intensive production and industrial sector transformation, coordinated development of regional systems and geographical optimization, environment and green technologies, quality of life of the population, global integration, quality governance, institutional regime and quality of institutions (UNDP China and the Institute..., 2013).

Many authors study the concept of sustainability from the standpoint of environmental safety and protection. Such authors as G.D. Atkinson, R. Dubourg, N. Chambers, K. Yin, R. Wang, S. F. Zhan, as well as many others (Atkinson et al., 1997; Nicholson, Chambers, Green, 2003; Bolcárová, Kološta, 2015; Wursthorn, Poganietz, Schebek, 2011; Yin et al., 2014; Zhan et al., 2012) are focused on the environmental aspect and environmental policy in their studies.

In recent decades studies by many authors have been focused on assessing the sustainable development of cities and other territories (Ding et al., 2016; Grzebyk, Stec, 2015; Bossel, 1999; Li et al., 2009; Moussiopoulos et al., 2010; Musakwa, Van Niekerk, 2015; Shen et al., 2015; Yin et al., 2014; Shen et al., 2011; Zhan et al., 2012; Xu et al., 2016; Wursthorn, Poganietz, Schebek, 2011).

The most comprehensive overview of the methodological approaches and tools used by different authors and organizations for assessing the sustainability 
of facilities of various levels (territories, companies and products) was made by such authors as R.K. Singh, H.R. Murty, S.K. Gupta and A.K. Dikshit (2009). The authors identified several levels of sustainability assessment. The division was carried out based on the assessment facilities (product, enterprise, industry and territory sustainability); methods and tools for assessing sustainability, focusing attention on specific aspects of this concept (innovative, environmental, technological, etc.), were grouped.

Some authors developed sustainability indicators systems, applicable to various industries. A. Azapagic (2004) considered sustainability in the context of industrial development. He developed a system of sustainability indicators for the mining industry. The indicators (sectoral indicators, reflecting the characteristics of an industry) were specifically developed for the industries mining minerals for metal, construction, energy and industrial sectors. His assessment system includes economic, environmental, social and integrated indicators that can be used both for the internal purposes of an industry's development, for identifying problematic aspects of the territory's industry development, as well as for making decisions by the authorities. In the study, the author sets a goal to ensure interaction of sectoral institutions with stakeholders (territorial authorities, management of other industries enterprises, etc.), to standardize corporate reports and provide a comparison of the level of industries and their enterprises' sustainability. In addition to that, the indicators structure developed by Adisa Azapagic is compatible with the sustainability indicators proposed by the Global Reporting Initiative (GRI).

D. Krajnc and P. Glavic (2005) developed a set of sustainability indicators for companies. The authors focused particular attention on the consideration of how to use the indicators they proposed to monitor sustainable development of a company. The purpose of their work was the model of sustainable development's composite index to track integrated information about the economic, environmental and social indicators of a company over time. Normalized by the linear method indicators were combined into three sub-indexes of sustainability and aggregated into the overall performance indicator of a company. The aggregation into the overall performance indicator was carried out by determining the influence of a separate indicator on the overall sustainability of a company using the analytic hierarchy concept. D. Krajnc and P. Glavic tested the proposed model for assessing a company's sustainability for Henkel over the period of 6 years, showing the broadest approach to understanding sustainability in action. The authors' interpretation of the study results proves the 
adequacy and effectiveness of assessments using the sustainability index for decisionmaking developed by them (Krajnc, Glavic, 2005).

Richard Poenitz (2014) studied and assessed product sustainability (of consumer electronic products) at different stages of its life cycle. The development and presentation of the concept capable of solving the issue of assessing the sustainability of products was the main purpose of his study. The author points to a lot of information, some of which, important and useful, is difficult to access for a researcher, and introduces the term of global product sustainability, assuming that "sustainable products" development is one of the key challenges facing the industry in the $21^{\text {st }}$ century. In the process of sustainability assessment, he proposes to use SMART indicators, developed in 1995, that meet the requirements of the US Department of Energy.

R. Poenitz recognizes the advantages of the widely accepted method of data standardization (in relation to the average value), which are in the simplicity and brevity of the method and the possibility to compare different products and companies. He substantiates the need to assess a company's sustainability considering previous and subsequent participants in the supply chain, at all the stages of a product life cycle, from raw material extraction to processing and reuse. As a tool for assessing sustainability, R. Poenitz uses a number of approaches, in particular, the expert method for assessing the significance of sustainability indicator (the author traditionally divides indicators into three blocks - economic, social and environmental ones), and the method of aggregating indicators by summing up the compositions of indicators and their significance (value) for the overall stability index of the objects under study (Poenitz, 2014).

Nadine Madanchi (2013) offers a tool aimed at assessing the sustainability of an individual enterprise within an industry. A set of indicators which is integrated into the overall composite index acts as a tool for sustainability assessment. The tool developed by the author is implemented using a specially created software product that gives an opportunity to cope with the task of assessing the sustainability of a plant (enterprise) time-effectively (Madanchi, 2013).

In 2017, rating agency SGM prepared a report "Tools and Features for Assessing Sustainable Development of Cities and Regions of Russia", calling for the implementation of sustainable development projects to improve sustainability, investment attractiveness of cities, regions and companies, and improve the quality of life of the Russian population. The Agency has been developing and publishing ratings of Russian cities and regions regarding various sustainability criteria since 2013. 
RIA Rating agency has been publishing regions' rating for the quality of life (from 2012) and the rating of the socio-economic status of constituent entities of the Russian Federation (2011-2015). Each rating is based on the Agency's own methods for assessing the indicators and composite indexes.

Sustainable development issues are studied by the following authors: S. N. Bobylev and B.N. Porfir'ev (Bobylev, Porfir'ev, 2016), T.N. Gul' (Gul', 2011), A.A. Maltseva (Maltseva, 2016), O.A. Sidyakina and A.V. Sayapin (Sidyakina, Sayapin, 2015), E. V. Korchagina (Korchagina, 2012), E.A. Zakharchuk and A.F. Pasynkov (Zakharchuk, Pasynkov, 2008).

In 2011, the project Mechanisms for Ensuring Sustainable Development of Large Cities and Their Global Network (the Case of Moscow) was developed within the framework of the programme Monitoring and Management of Global Processes in Large Cities and within the framework of the activities of the Moscow UNESCO Chair at Moscow State University (authors: E. V. Berezovsky, A. O. Bessonov, A. A. Vaulina, I. M. Vershinina, E. Ya. Vinokur, R.R. Gabdullin and G.A. Drobot).

Let us turn attention to the approaches and tools for assessing the sustainability of cities, countries and regions (territories). The methods of standardization, weighting and aggregation are the most common approaches to assessing territories sustainability. All the authors who overviewed methodologies for sustainability assessment agree with this.

The most problematic assessment stage is the procedure of weighing or determining the significance of the selected indicators for the overall sustainability index. To solve this task, some authors use the subjective method (expert evaluation method), which includes analytic hierarchy process (Krajnc, Glavic, 2005; Veisi, Liaghati, Alipour, 2016) and the Delphi method (García-Melón, Gómez-Navarro, Acuña- Dutra, 2012).

The subjective method has obvious drawbacks, but at the same time it has a clear benefit in terms of information accessibility. A necessary condition is proper organization of the Delphi method (find the required number of experts, formulate the assessment question correctly, ensure the independence of expert answers, and process the results of their answers and assessments). There are no restrictions on data availability with the use of this approach. Experts formulate answers and assessments at their discretion, based on their knowledge, experience and qualification.

The objective method determines the weight of each index based on the internal interrelation and variation degree among the various indicators and is complicated by the need to use a precise mathematical apparatus. Therefore, it is necessary to indicate the 
difficulty of collecting statistical data, based on which the weight (significance) of each indicator of sustainability is determined, as its main drawback. This approach includes the methods for calculating the degree of variation between different indicators, the principal component analysis (Grzebyk, Stec, 2015; Tan, Lu, 2016; Bolcárová, Kološta, 2015), the entropy method (Zhao, Chai, 2016; Shen et al., 2015), the correlation and factor analysis (Lee, 2013). All the aforementioned methods overcome the drawback of the subjective approach but are more difficult to implement.

In this way, the study of modern authors' works in the field of assessing sustainability of territories' development has shown that the main approaches and tools are as follows:

1) assessment of the integral indicator of sustainability, which includes several parameters of socio-economic sustainability of the territory: economic, production, financial and investment, budget, social and environmental indicators, reduced to the system of indices;

2) dynamic analysis of the indicators reflecting certain aspects of sustainability, using comparative characteristics of territories and periods of analysis (rapid assessment of a territory sustainability based on monitoring the indicators);

3) calculation of coefficients and ranks, making the ratings of the territories under study based on statistical and expert indicators;

4) artificial neural network methods and scenario approach.

A lot of the applied author's approaches are completed by building typological groupings of territories based on integral indicators of development sustainability (division by the level of sustainability). Sometimes the authors suggest threshold or regulatory values for socio-economic systems sustainability.

\section{Statement of the problem}

The results of the studies on the Russian regions sustainability conducted by various Russian authors suggest that about half of the population of the Russian Federation lives in the areas with the signs of unsustainable development (Skopin, A.O., Skopin, O.V., 2010). Most of these Russian regions are the resource base of the country and provide transport links between the remote territories. For this reason, there is an objective need of search and development of promising factors for sustainable development of territories. The problematic aspects of the Russian regions are unfavorable institutional environment, contributing to the export of capital to the European part of the state and other countries; geographic remoteness from the world market and developed regions of the country; raw material base depletion and its deterioration in the quality aspect; 
insufficient development of transport infrastructure and low effectiveness of measures to attract investment at the regional level.

The priorities of the state policy in relation to the regions characterized as unsustainable should involve ensuring a steady growth in the quality and standard of living of the population on the basis of a balanced economic system. The balance of the system ensures economic development and implementation of the strategic interests of unstable regions through the development of the structures of the automotive, railway and pipeline transport; industry, agro-industrial and energy complex, processing industry, etc.

The solution of the aforementioned tasks will provide these territories with an opportunity to create conditions for attracting investments into projects, including creation of new and expansion of the existing enterprises, as well as territorial production complexes that ensure increased sustainability of the regions.

Effective implementation of these tasks is impossible without timely and constant monitoring of socio-economic indicators and development parameters. Researches developed a significant number of tools for assessing and analyzing socio-economic statistics, but the search for new approaches and methods to monitor the situation in the regions and their sustainability continues. The reason for this is drawbacks in the existing approaches, that significantly complicate their implementation, limit their applicability and reduce the level of confidence in the evaluation results. Moreover, there is no clear relationship between the assessment of the territories' sustainability and the cluster approach to ensure stable growth in the researches' studies. Territorial development policy, as a rule, is faced with a choice between economic efficiency and equality. This is a dilemma between adopting a policy aimed at ensuring the growth of the economy in general using the most efficient (cost-effective) methods and adopting a policy aimed at developing certain territories within the economy (based on the considerations of economic and social justice). In the cluster policy, which is a modification of the "growth points" theory, this choice was made in favor of economic efficiency.

The authors of studies in the field of cluster policy evaluate the efficiency of a cluster or its enterprises functioning (Suresh, Erinjery, Jegathambal, 2016; Suchacek, Stverkova, 2018; Bembenek, 2015), recognize and justify the important role of clusters in ensuring regional economic systems sustainability (Narizhny, Golosov, 2013), but do not pay enough attention to assessing the strength of clusters and territorial production complexes influence on the sustainable development of the territories within these 
structures. Therefore, the role of assessment in this case is not only to determine whether there is growth in the clusters, but also to determine whether this growth has a positive impact on the entire economy of a region. It should be recognized that such studies exist (Cunha, S.K., Cunha J.C., 2005; Kutsenko, 2015; Njøs, Jakobsen, 2016; Anselin, 1995; Tsertseil, Kookueva, 2018; McCunn, 2001), however, there is still a need to search and expand the toolkit for assessing the sustainability of the territories development within the frames of the cluster approach. It should be emphasized that the importance of assessment is not only in measuring the direct result of the cluster policy, but also in its role as a catalyst for deep economic changes.

The study of the situation in the field of economic and social development of territories is of practical importance to develop recommendations for decision-making to regional authorities.

\section{Theoretical framework}

The concept of sustainability was borrowed by the economic science from the theory of systems, when economic agents started to be seen as complex and open to the external effects of the system. The sustainability of an agent means that when exposed to endogenous factors, it maintains its stability or can return to its former state (restore its internal structure and actions).

The issues of sustainability in relation to economic problems were first reflected in theoretical papers devoted to market equilibrium under conditions of perfect competition (L. Walras, A. Marshall, P. Samuelson, A. Wald).

The issues of market sustainability were studied in the scientific works (Walras, 2000; Samuelson, 2002; Schumpeter, 2011). Conclusions that underlie the formation of the modern theory of economic sustainability, in particular, about disproportions in income distribution, inconsistency of forecast expectations and real outcomes of economic life as the reasons for the loss of sustainability, as well as strengthening the regulatory role of the state in order to maintain sustainability were obtained.

The issues of economic sustainability were further developed in the works by A.A. Bogdanov (Biggart, Gloveli, Yassour, 1998). The relationship between the sustainability of systems of different levels was studied in his works in detail, and it was proved that the system sustainability is determined by the sustainability of structural connections between its elements.

Modern trends in the theory of economic sustainability are formed by neoinstitutionalism, within which institutions play a significant role, and this role is to 
reduce the degree of environmental uncertainty by establishing strong and reliable (stable) connections between economic actors.

Within the framework of the neoclassical theory, development sustainability is characterized by the preservation of the level of per capita consumption of the population, depending on non-negative change of capital reserves value over time. The conservationist approach defines sustainable development as the maximum one, that can be achieved without reducing the assets of the natural capital of a nation. The ecological economic approach is based on the need to coordinate environmental protection processes and to meet social and economic needs.

The sustainable development paradigm, which involves a dynamic process of successive positive changes that ensure the balance of all aspects, underlies the formation of approaches to solve the problems of territorial entities.

The definition of "sustainable development" is used to denote the type of economic development that ensures safe functioning of all links and elements of a socio-economic system. In their studies the authors recognize the environmental aspect, the state of environment, limited resources reproducibility and the quality of economic growth as priority aspects of safety. Ultimately, the sustainable development of a territory is aimed at achieving a high level of quality of life for the population with a positive dynamic of a set of socio-economic indicators.

The sustainable development of a territory determines the ability of a region to maintain and increase the value of the necessary parameters of the quality of life of the population within a certain level of security (economic, social, political, technological, environmental, etc.). This concept should be considered comprehensively, and the interpretation of this term only from the economic, social or environmental side is narrow and not capable of reflecting all the aspects of the concept.

In this study stable (sustainable) socio-economic development of the territory is understood as a set of socio-economic development characteristics:

- systematic increase in quantitative and qualitative parameters of the socioeconomic system of a territory's (region's) functioning;

- simultaneous and non-conflicting processes of positive dynamics of production, social, economic, environmental, budgetary and other spheres' aspects;

- maintaining the stability of a certain level of socio-economic indicators (stabilizing sustainability) or maintaining the growth of specified indicators (gross regional product, income level of the population, social services provision indicators, etc.) - dynamic sustainability. 
Therefore, economic sustainability is a dynamic concept that characterizes the process of development of the socio-economic systems that do not deviate from the trajectory of movement and do not deteriorate their basic parameters when exposed by external factors.

\section{Methods}

It is suggested to evaluate sustainable development of territories taking into account multiplicative effects of interregional and intersectoral interaction (cluster overflows on the basis of the TOPSIS method (the Technique for Order Preference by Similarity to Ideal Solution), which advantage is the opportunity to solve a task of decision making with an infinite number of alternatives. Two criteria ("the shortest distance to a positive ideal solution" and "the longest distance to a negative ideal solution") are substituted by the criterion "as close to PIS as possible" and "as far from NIS as possible".

There are following stages of the TOPSIS method application: building a system for index monitoring, assessing and analyzing sustainability of the territories development; application of the assessment method and the method of indicators weighing; assessment of the calculations sustainability when altering individual parameters, and assessment of structural shifts in the territorial-production system of the region under the influence of changes in economic relations, market processes, interregional and intersectoral relations.

The TOPSIS model (The Technique for Order Preference) was first offered by C.L. Hwang and K. Yoon in 1981 (Hwang, Yoon, 1981). This comprehensive assessment method, based on distance calculation, is widely used for making decisions by domestic and foreign authors, mainly in assessing the reliability of transport, information and engineering systems (Li, Zhao, Suo, 2014; Huang, 2008; Wang, Elhag, 2006; Ghobadi, Heshmatpour, 2015; Wang, Lee, 2007; Antamoshkin, 2009).

In economic research, the method is mainly used for solving the tasks of assessing competitive advantages of business and personnel management (Torlak et al., 2011; Sun, Lin, 2009; Madanchi, 2013; Gungor, Serhadlıglu, Kesen, 2009; Kelemenis, Askounis, 2010; Nobari, 2011; Chien, Chen, 2008; Chen, 2009; Mamedova, Dzhabrailova, 2015).

The TOPSIS model can objectively and comprehensively reflect the level of sustainable development of a territory, calculating the degree of proximity between the estimated (current) situation in the socio-economic system and its ideal state.

In this study, the sustainable development of a territory is understood as the joint development of regions and municipalities interacting within the framework of 
economic cooperation, which excludes deterioration of socio-economic indicators as a result of a project implementation compared to the current level of individual territorial units' development. When assessing the level of territories'development sustainability, it is proposed to carry out monitoring in the following areas:

- budget aspect (budgetary expenditures - investments and budget losses as a result of providing tax incentives and preferences; tax revenues as a result of investment projects implementation);

- social aspect (incomes of a territory's population, employment, provision of social facilities);

- transport infrastructure (increase in the length and traffic capacity of the transport and logistics infrastructure);

- economic aspect (manufactured items growth, fixed assets renewal, inflow of private investment in the real economy sector, etc.).

The budget aspect of sustainability involves a balanced state of public finances, allowing territorial authorities to fulfill their responsibilities in the managed areas to the full extent.

The economic approach to the concept of sustainable development of a territory implies the optimal use of limited resources and the existing advantages of a territory in the manufacturing and services sectors.

The social aspect of sustainable development is focused on person and is aimed at improving the quality of life in all its aspects: income, health care and education.

Within the aspect of transport infrastructure sustainable development of a region implies reducing dependence on the transport and logistics routes of other territories (regions), allowing to reduce production costs and improve socio-economic situation.

Within the frames of assessing sustainability of the territories involved into the implementation of several interrelated investment projects (projects portfolio), a requirement for achieving indicators of socio-economic development (in selected sustainability areas) is established: as close as possible to the planned level (for the optimistic variant of the projects implementation) and as far as possible from the negative variant of the projects implementation (for the pessimistic variant). The fulfillment of the requirement is possible by applying the Technique for Order Preference by Similarity to Ideal Solution (TOPSIS). The general logic of the method and its practical application was given in detail by Lin Ding, Zhenfeng Shao, Hanchao Zhang, Cong Xu and Dewen $\mathrm{Wu}$, case study the cities in China (Ding et al., 2016). A lot of criteria that are assumed within this method, are reduced to the selected 
areas (aspects) of sustainability. According to the TOPSIS concept, the identified alternative must have the shortest geometric distance from the positive ideal solution (PIS) and the longest geometric distance from the negative ideal solution (NIS) (Table 1).

The use of this method also raises the issue of determining the weights (significance) of the criteria used (directions or aspects of sustainability). Unprocessed data of sustainability indicators in the form of a matrix with $m \bullet n$ scale, where $m$ is the number of assessment objects (territories), and $n$ is the number of indicators (sustainability criteria or indicators) is used to calculate weighting coefficients:

$$
X=\left[\begin{array}{cccc}
x_{11} & x_{12} & \cdots & x_{1 n} \\
x_{21} & x_{22} & \cdots & x_{2 n} \\
\vdots & \vdots & \vdots & \vdots \\
x_{m 1} & x_{m 2} & \cdots & x_{m n}
\end{array}\right]
$$

with $x_{i j}$ is the initial value of sustainability indicator.

Structural differences indicator - V.M. Ryabtsev index (Ryabtsev, 2002) is one of the effective tools for analyzing quantitative changes in individual sustainability criteria and assessing structural shifts in the territorial production system of a region under the influence of changes in economic relations, market processes, interregional and intersectoral relations. The index characterizes differences in the indicator structure at two time intervals and makes it possible to judge about the sustainability of the economic system development. The index is calculated as a ratio of the actual measure of the differences in the values of the components of two structures with their maximum possible value:

$$
R_{i}=\sqrt{\frac{\sum_{j=1}^{n}\left(P_{i j}^{1}-P_{i j}^{0}\right)^{2}}{\sum_{j=1}^{n}\left(P_{i j}^{1}+P_{i j}^{0}\right)^{2}}}
$$

where $R_{i}$ is the index of structural differences of the $i$-th territory sustainability component; $P_{i j}^{1}$ is estimated values of $j$-th stability criterion of $i$-th territory, achieved under the influence of changes in economic relations, market processes, interregional and intersectoral relations; $P_{i j}^{0}$ is assessed values of the $j$-th stability criterion of $i$-th territory, determined at the initial stage of study (before assessing the impact of territories interaction within a cluster). 


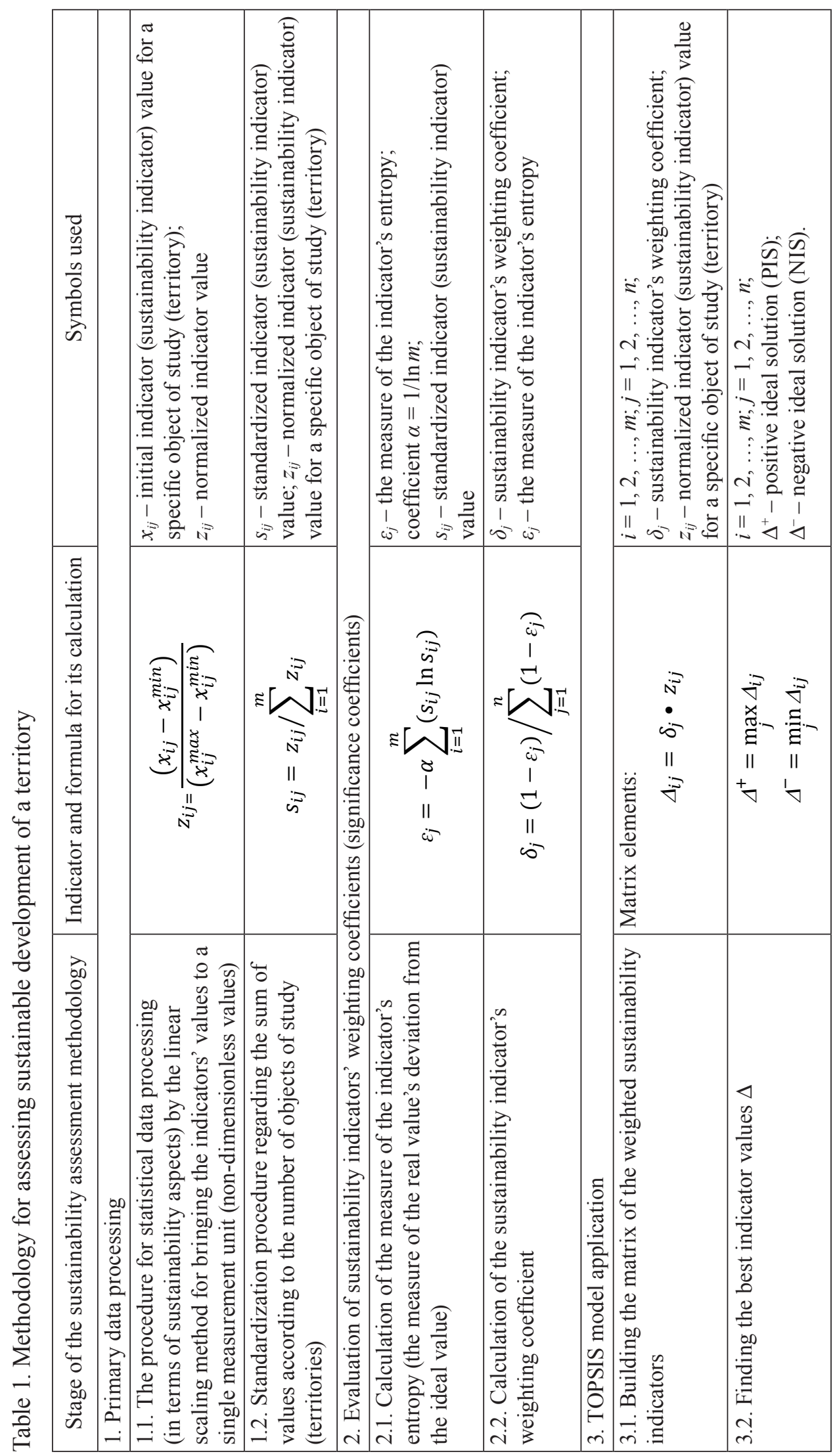




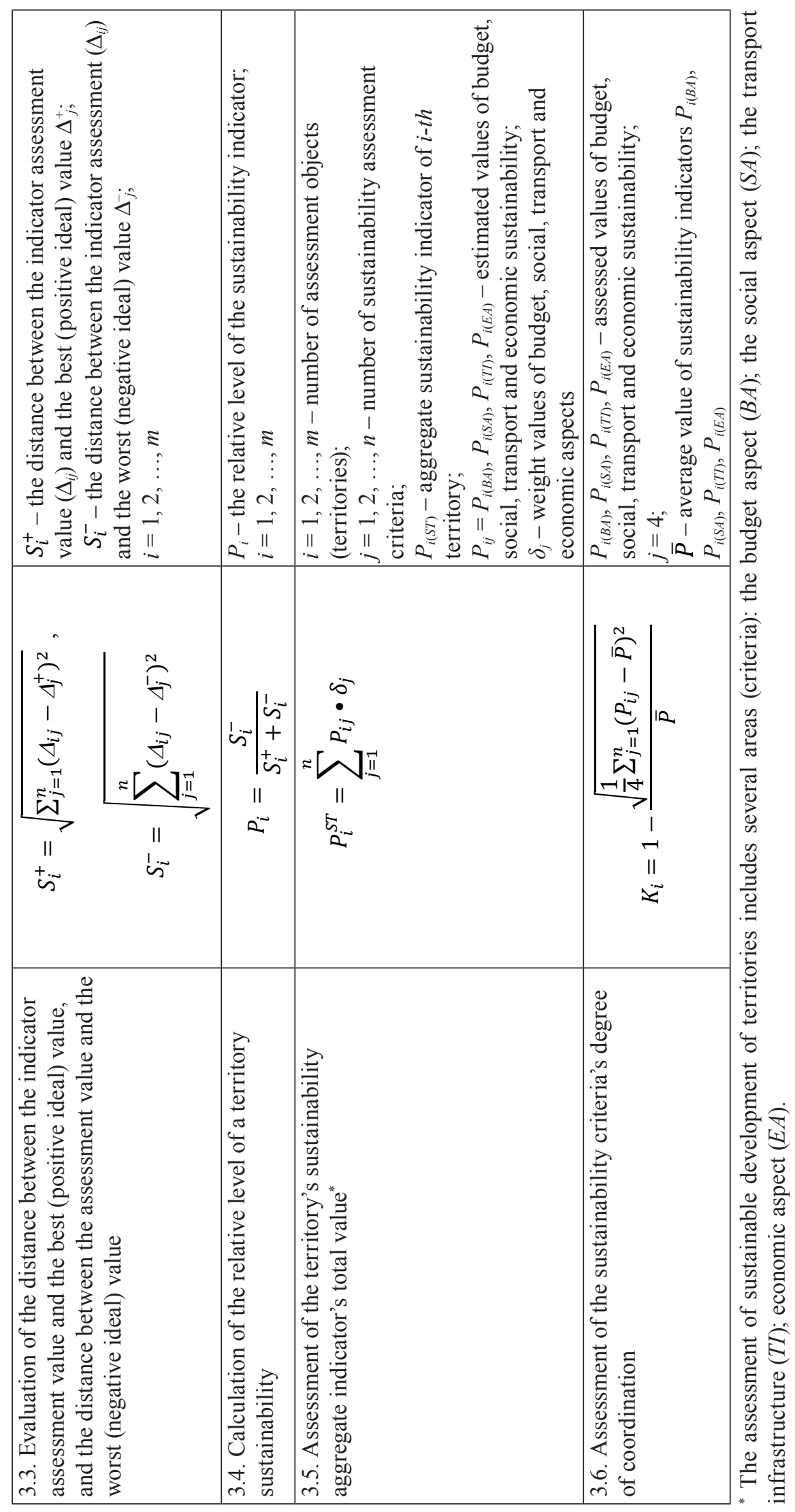


The following intervals of structural differences criterion values are introduced: [0; 0.03] - structures identity; [0.031;0.07] - very low level of differences; [0.071;0.15] low level of differences; [0.151; 0.3] - significant level of differences; [0.301; 0.5] considerable level of differences; [0.501; 0.7] - very considerable level of differences; $[0.701 ; 0.9]$ - opposite type of structures; $[0.901 ; 1]$ - completely opposite structures.

\section{Discussion}

The current stage of the country's economy development is characterized by the extensive complex of regional problems, and a lot of scientists' studies and reforms of different levels of authorities are aimed to their solution. A lot of programs within the national economy, as well as at the regional and local levels are being developed and implemented. Various methods and tools to manage the development of socioeconomic systems and to ensure their sustainability are offered. Regional authorities offer strategies for socio-economic development of regions, which include a list the competitive advantages of regional systems, their strengths and weaknesses, as well as areas and development prospects, the necessary measures to improve socio-economic situation of a territory and ways to achieve the goals set.

The issue of sustainable socio-economic development is particularly relevant for the territories with a narrow range of specialization areas. Territories that exist and develop due to enterprises of one or several interconnected industries have high risks in terms of ensuring sustainability. A fundamental change in the territory's specialization is impossible due to objective reasons: the presence of some natural resources, the existing production potential, geographical advantages and restrictions, etc. The world practice of managing territorial development has shown that in such a situation it is reasonable and efficient to use cluster policy to ensure sustainability and solve problems of territories. If the "growth points" development processes are efficient, then this growth will most likely lead to a positive effect of the rest of the economy than to the effect of "pulling out" resources through an indirect increase in sales, growth in the number of jobs and workforce skills levels, as well as expanding prospects of scientific and technical developments. Growth in the economic sectors that form clusters may attract unused (or underutilized) resources from other parts of the economy, as well as through foreign investment that are also external to the economic system. The cluster model of sustainable development of territories implies that it is the cluster that acts as an effective tool of regional policy, ensuring coordinated development of all the aspects of sustainability due to the intersectoral and interregional interactions of the cluster participants (elements). 
Being the latest and most adequate under conditions of competitive market economy, the cluster approach in economic policy has been recognized by foreign scientists and implemented in several countries. In the process of regional policy adoption, the cluster approach should not be understood in a limited way, for instance, only in terms of the geographical concentration of enterprises and production infrastructure. The territorial proximity of industrial facilities within urban agglomerations often causes growing social discontent and entails environmental problems, but does not solve the problem of sustainable socio-economic development of a territory.

In recent years, Russian researchers have followed the methodology of leading economists, but the idea of the cluster approach used in the process of regional industrial policy development lacks original ideas and faces difficulties in its implementation under the conditions of the existing production structure.

Development of methodological approaches to sustainable development assessment in the context of cluster approach will give an opportunity to identify the basis for the regional cluster policy formation, taking into account the integration component. It will also contribute to the development of the issue of assessing the determinants of territorial systems sustainability, as well as to the implementation of a strategy for sustainable socio-economic development of territories based on the proposed methodological tool.

\section{Conclusion}

Quantitative assessment of sustainable development of territories is traditionally based on a set of measured indicators and indicators for conducting regular monitoring of the situation. This approach also gives an opportunity to identify missing (rarely taking into account due to the complexity of assessment procedure) monitoring areas that need control to achieve the overall goal of improving sustainability.

The authors use indicators and methods for assessing socio-economic development and its sustainability adapted for statistical data within the framework of the designed monitoring mechanism. The system of indicators consisting of four aspects: budget, social, economic and transport infrastructure has been developed for quantitative assessment of the level of sustainable development of the territories.

The methodology used to assess sustainable development should consider the basic principles of cluster methodology, that is, be implemented taking into account the multiplicative effects of interregional and intersectoral interaction. For this purpose, 
it is suggested to adapt the TOPSIS method (the Technique for Order Preference by Similarity to Ideal Solution), which advantage is the ability to solve the decisionmaking task with an infinite number of alternatives.

\section{References}

Anselin, L. (1995). Local Indicators of Spatial Association. In Geographical Analysis, 27, 3-115.

Antamoshkin, O.A. (2009). Sistema podderzhki priniatiia reshenii na osnove mnogoatributivnykh metodov [Decision Support System Based on Multi-Attribute Methods]. In Vestnik SibGAU [SibSAU Bulletin], 4(25), 69-71.

Atkinson, G.D., Dubourg, R., Hamilton, K., Munasinghe, M., Pearce, D.W., Young, C. (1997). Measuring Sustainable Development: Macroeconomics and the Environment. Cheltenham, Edward Elgar Publishing Ltd. Available at: http://eprints. 1se.ac.uk/id/eprint/32040 (accessed 10 February 2019).

Azapagic, A. (2004). Developing a Framework for Sustainable Development Indicators for the Mining and Minerals Industry. In Journal of Cleaner Production, 12, 639-662. DOI: 10.1016 /S0959-6526(03)00075-1.

Bembenek, B. (2015). The Sustainable Development of an Industrial Cluster in the Context of Corporate Social Responsibility - a New Challenge for Cluster Management. In European Scientific Journal, 1, 225-235. Available at: https://eujournal.org/index. php/esj/article/viewFile/5090/4862 (accessed 10 February 2019).

Bhada, P., Hoornweg, D. (2009). The Global City Indicators Program: a More Credible Voice for Cities. Washington DC, World Bank, 4 p. Available at: https://openknowledge.worldbank.org/handle/10986/10244 (accessed 10 February 2019).

Biggart J., Gloveli, G., Yassour, A. (1998). Bogdanov and His Work: a Guide to the Published and Unpublished Works of Alexander A. Bogdanov (Malinovsky) 18731928. New York, Routledge, 504 p.

Bobylev, S.N., Porfir'ev, B.N. (2016). Ustoichivoe razvitie krupneishikh gorodov i megapolisov: faktor ekosistemnykh uslug [Sustainable Development of Major Cities and Megacities: The Factor of Ecosystem Services]. In Vestnik Moskovskogo universiteta [Moscow University Bulletin], 6, 3-21.

Bolcárová, P., Kološta, S. (2015). Assessment of Sustainable Development in the EU27 Using Aggregated SD Index. In Ecological Indicators, 48, 699-705. DOI: 10.1016/j.ecolind.2014.09.001. 
Bossel, H. (1999). Indicators for Sustainable Development: Theory, Method, Applications. A Report to the Balaton Group. Manitoba, International Institute for Sustainable Development, $124 \mathrm{p}$.

Chen, P.-C. (2009). A Fuzzy Multiple Criteria Decision-Making Model in Employee Recruitment. In International Journal of Computer Science and Network Security, 9(7), 113-117.

Chien, C.F., Chen, L.F. (2008). Data Mining to Improve Personnel Selection and Enhance Human Capital: A Case Study in High-Technology Industry. In Expert Systems with Applications, 34 (2), 280-290. DOI: 10.1016/j.eswa.2006.09.003.

Chua, L.H. (2006). The Singapore Green Plan 2012. Singapore, Ministry of the Environment and Water Resource, 82 p. Available at: http://unpan1.un.org/intradoc/ groups/public/documents/apcity/unpan026598.pdf (accessed 10 February 2019).

Commission on Sustainable Development (2001). Indicators of Sustainable Developmen: Guidelines and Methodologies. New York, United Nations Department of Economic and Social Affairs, 93 p. Available at: https://sustainabledevelopment. un.org/content/documents/guidelines.pdf (accessed 10 February 2019).

Cunha, S.K., Cunha J.C. (2005). Tourism Cluster Competitiveness and Sustainability: Proposal for a Systemic Model to Measure the Impact of Tourism on Local Development. In BAR, 2(4), 47-62.

Department of the Environment of United Kingdom(1996). Indicators of Sustainable Development for the United Kingdom: a set of indicators produced for discussion and consultation by an interdepartmental working group, following a commitment in the UK's sustainable development strategy of 1994. London, HMSO, 196 p. Available at: https://www.worldcat.org/title/indicators-of-sustainable-development-for-the-unitedkingdom-a-set-of-indicators-produced-for-discussion-and-consultation-by-aninterdepartmental-working-group-following-a-commitment-in-the-uks-sustainabledevelopment-strategy-of-1994/oclc/37220870 (accessed 10 February 2019).

Ding, L., Shao, Z., Zhang, H., Xu, C., Wu, D. (2016). A Comprehensive Evaluation of Urban Sustainable Development in China Based on the TOPSIS-Entropy Method. In Sustainability, 8(746). DOI:10.3390/su8080746.

García-Melón, M., Gómez-Navarro, T., Acuña-Dutra, S. (2012). A Combined ANP-Delphi Approach to Evaluate Sustainable Tourism. In Environmental Impact Assess, 34, 41-50.

Ghobadi, M., Heshmatpour, M. (2015). Comparing Profitability and Ranking of Technical Analysis Indicators Based on TOPSIS Technique. In Voprosy upravleniia [Management Issues], 4(16), 167-180. DOI:10.5937/ekonomika1504167G. 
Global Reporting Initiative (2002). Sustainability Reporting Guidelines. Amsterdam, Global Reporting Initiative, 96 p. Available at: https://www.epeat.net/ documents/EPEATreferences/GRIguidelines.pdf (accessed 10 February 2019).

Grzebyk, M., Stec, M. (2015). Sustainable Development in EU Countries: Concept and Rating of Levels of Development. In Sustainable Development, 23, 110-123. DOI:10.1002/sd.1577.

Gul', T.N.(2011). Otsenkaustoichivosti razvitiia regiona [Estimation of Development Stability of the Region]. In Sotsial'no-ekonomicheskie yavleniya i protsessy [SocioEconomic Phenomena and Processes], 10(032), 34-39.

Gungor, Z., Serhadlioglu, G., Kesen, S.E. (2009). A Fuzzy AHP Approach to Personnel Selection Problem. In Applied Soft Computing, 9, 641-649. DOI: 10.1016/j. asoc.2008.09.003.

Huang, J. (2008). Combining Entropy Weight and TOPSIS Method for Information System Selection. In Proceedings of the 2008 IEEE Conference on Cybernetics and Intelligent Systems, Qingdao, IEEE, 1965-1968. DOI: 10.1109/ICAL.2008.4636483.

Hwang, C.L., Yoon K. (1981). Multiple Attributes Decision Making Methods and Applications. Berlin, Springer-Verlag Berlin Heidelberg, 269 p. DOI: 10.1007/978-3642-48318-9.

Kelemenis, A., Askounis, D. (2010). A New TOPSIS-Based Multi-Criteria Approach to Personnel Selections. In Expert Systems with Applications, 37(6), 4999 5008. DOI: 10.1016/j.eswa.2009.12.013.

Korchagina, E.V. (2012). Metody otsenki ustoichivogo razvitiia regional'nykh sotsial'no-ekonomicheskikh sistem [Methods for Assessing the Sustainable Development of Regional Socio-Economic Systems]. In Problemy sovremennoy ekonomiki [Problems of the Modern Economy], 1, 67-71.

Krajnc, D., Glavic, P. (2005). A Model for Integrated Assessment of Sustainable Development. In Resources, Conservation and Recycling, 43, 189-208. DOI: 10.1016/j. resconrec.2004.06.002.

Kutsenko, E. (2015). Pilot Innovative Territorial Clusters in Russia: A Sustainable Development Model. In Foresight-Russia, 9(1), 32-55. DOI: 10.17323/1995459X.2015.1.32.55.

Lee, T.H. (2013). Influence Analysis of Community Resident Support for Sustainable Tourism Development. In Tour Management, 34, 37-46.

Li, F., Liu, X., Hu, D., Wang, R., Yang, W., Li, D., Zhao, D. (2009). Measurement Indicators and an Evaluation Approach for Assessing Urban Sustainable Development: 
A Case Study for China’s Jining City. In Landscape and Urban Planning, 90(3), 134142. DOI: 10.1016/j.landurbplan.2008.10.022

Li, Y., Zhao, L., Suo, J. (2014). Comprehensive Assessment on Sustainable Development of Highway Transportation Capacity Based on Entropy Weight and TOPSIS. In Sustainability, 6, 4685-4693. DOI:10.3390/su6074685.

Madanchi, N. (2013). A Rapid Assessment Tool to Assess Factory Sustainability. In Open Access Master's Theses, 133. Available at: https://digitalcommons.uri.edu/ theses/133 (accessed 10 February 2019).

Maltseva, A.A. (2016). Metodicheskie podkhody k otsenke ustoichivosti territorii innovatsionnogo razvitiia $\mathrm{s}$ ispol'zovaniem teorii dinamicheskikh normativov [Methodical Approaches to Assessing the Sustainability of Innovation Development Areas Using the Theory of Dynamic Standards]. In Mezhdunarodnyi bukhgalterskii uchet [International Accounting], 6(396), 41-60.

Mamedova, M.G., Dzhabrailova, Z.G. (2015). Mnogokriterial'naia optimizatsiia zadach upravleniia chelovecheskimi resursami na baze modifitsirovannogo metoda TOPSIS [Multi-Criteria Optimization of Human Resources Management Tasks Based on the Modified TOPSIS Method]. In Vostochno-Evropeiskii zhurnal peredovykh tekhnologii [East European Journal of Advanced Technologies], 2/4(74), 48-61.

McCunn, A.L. (2001). An Economic Analysis of Inter-Regional and Inter-Sectoral R\&D Spillovers as Sources of Economic Growth. Retrospective Theses and Dissertations, 439 p. Available at: https://lib.dr.iastate.edu/rtd/439 (accessed 10 February 2019).

Moussiopoulos, N., Achillas, C., Vlachokostas, C., Spyridi, D., Nikolaou, K. (2010). Environmental, Social and Economic Information Management for the Evaluation of Sustainability in Urban Areas: A System of Indicators for Thessaloniki, Greece. In Cities, 27, 377-384. DOI:10.1016/j.cities.2010.06.001.

Musakwa, W., Van Niekerk, A. (2015). Monitoring Sustainable Urban Development Using Built-Up Area Indicators: A Case Study of Stellenbosch, South Africa. In Environment Development and Sustainability, 17(3), 547-566. DOI: 10.1007/s10668014-9560-7.

Narizhny, I.V., Golosov, O.V. (2013). Rol' klasterov v obespechenii ustoichivosti regional'nykh ekonomicheskikh system [The Role of Clusters in Ensuring the Sustainability of Regional Economic Systems]. In Sotsial'no-ekonomicheskie iavleniia i protsessy [Socio-Economic Phenomena and Processes], 7(053), 109-114.

Nicholson, I.R., Chambers, N., Green, P. (2003). Ecological Footprint Analysis as a Project Assessment Tool. In Engineering Sustainability, 156(ES3), 139-145. Available 
at: http://www.homepages.ucl.ac.uk/ ucessjb/S3 \%20Reading/nicholson\%20et\%20 al\%202003.pdf (accessed 10 February 2019).

Njøs, R., Jakobsen, S.E. (2016). Cluster Policy and Regional Development: Scale, Scope and Renewal. In Regional Studies, Regional Science, 3(1). 146-169. DOI:10.108 0/21681376.2015.1138094.

Nobari, S. (2011). Design of Fuzzy Decision Support System in Employee Recruitment. In Journal of Basic and Applied Scientific Research, 1(11), 1891-1903.

Organization for Economic Co-Operation and Development (2001). OECD Environmental Indicators: Towards Sustainable Development. Paris, OECD, 156. Available at: https://www.oecd.org/site/worldforum/33703867.pdf (accessed 10 February 2019).

Poenitz, R. (2014). Assessing Global Product Sustainability of Consumer Electronic Products - Development of an Integrated Approach. In Open Access Master's Theses, 366. Available at: http://digitalcommons.uri.edu/theses/366 (accessed 10 February 2019).

Ryabtsev, V.M. (2002). Konkurentosposobnost' rossiiskikh regionov: metodologiia otsenki isravnitel'nogo analiza [Competitiveness of Russian Regions: An Assessmentand Comparative Analysis Methodology]. Samara, Izdatel'stvo Samarskoi gosudarstvennoi ekonomicheskoi akademii, $127 \mathrm{p}$.

Samuelson, P.E. (2002). Osnovaniia ekonomicheskogo analiza [The Foundations of Economic Analysis], St. Petersburg, Ekonomicheskaia shkola, 604 p.

Schumpeter, J. (2011). Desiat' velikikh ekonomistov ot Marksa do Keinsa [Ten Great Economists from Marx to Keynes]. Moscow, Institut Gaidara, 400 p.

Shen, L., Zhou, J., Skitmore, M., Xia, B. (2015). Application of a Hybrid EntropyMcKinsey Matrix Method in Evaluating Sustainable Urbanization: A China Case Study. In Cities, 42, 186-194. DOI: 10.1016/j.cities.2014.06.006.

Shen, L.Y., Ochoa, J.J., Shah, M.N., Zhang, X. (2011). The Application of Urban Sustainability Indicators - a Comparison Between Various Practices. In Habitat International, 35, 17-29. DOI: 10.1016/j.habitatint.2010.03.006.

Sidyakina, O.A., Sayapin, A.V. (2015). Instrumentarii obespecheniia ustoichivogo razvitiia agropromyshlennogo regiona [Toolkit to Ensure Sustainable Development of the Agro-Industrial Region]. In Sotsial'no-ekonomicheskie iavleniya i protsessy [Socio-Economic Phenomena and Processes], 4, 81-89.

Singh, R.K., Murty, H.R., Gupta, S.K., Dikshit, A.K. (2009). An Overview of Sustainability Assessment Methodologies. In Ecological Indicators, 9, 189-212. DOI: 10.3390/su8080746. 
Skopin, A.O., Skopin, O.V. (2010). Problemy ustoichivogo razvitiia regionov Rossii v usloviiakh formirovaniia rynochnykh otnoshenii [Problems of Sustainable Development of Russian Regions in the Conditions of Market Relations Formation]. In Upravlenie ekonomicheskimi sistemami [Management of Economic Systems], 4(24). Available at: http://uecs.mcnip.ru/modules.php?name=News\&file=article\&sid=295 (accessed 10 February 2019).

Suchacek, J., Stverkova, H. (2018). Czech Machinery Cluster and Its Role in Sustainable Development of Moravian-Silesian Enterprises during the PostTransformation Era. In Sustainability, 10(2), 239. DOI:10.3390/su10020239.

Sun, C.C., Lin, G.T. (2009). Using Fuzzy TOPSIS Method for Evaluating the Competitive Advantages of Shopping Websites. In Expert Systems and Applications, 36, 11764-11771. DOI: 10.1016/j.eswa.2009.04.017.

Suresh, B., Erinjery, J.J., Jegathambal, P. (2016). Indicators and Influence Factors for Sustainability Assessment of Inclusive Smart Innovation Clusters. In Journal of Geological Resource and Engineering, 7, 305-327. DOI:10.17265/23282193/2016.07.001.

Sustainable Development in the European Union. Key Messages (2015). Luxembourg, Publications Office of the European Union, 122 p. DOI: 10.2785/95503. Available at: https://ec.europa.eu/eurostat/documents/3217494/6987735/KS-GU-15001-EN-N.pdf (accessed 10 February 2019).

Tan, F., Lu, Z. (2016). Assessing Regional Sustainable Development Through an Integration of Nonlinear Principal Component Analysis and Gram Schmidt Orthogonalization. In Ecological Indicators, 63, 71-81.

The 13th Five-Year Plan for Economic and Social Development of the People's Republic of China (2011). Beijing, Central Committee of the Communist Party of China, 219 p. Available at: http://en.ndrc.gov.cn/policyrelease/201612/ P020161207645766966662.pdf (accessed 10 February 2019).

Torlak, G., Sevkli, M., Sanal, M., Zaim, S. (2011). Analyzing Business Competition by Using Fuzzy TOPSIS Method: An Example of Turkish Domestic Airline Industry. In Expert Systems and Applications, 38, 3396-3406.

Tsertseil, Yu.S., Kookueva, V.V. (2018). Perspektivy razvitiia territorii v ramkakh realizatsii klasternogo podkhoda $\mathrm{v}$ Rossiiskoi Federatsii [Prospects of Territories Development Within the Implementation of the Cluster Approach in the Russian Federation]. In Voprosy innovatsionnoi ekonomiki [Issues of Innovative Economy], 8(3). 365-374. DOI: 10.18334/vinec.8.3.39363. 
UNDP China and Institute for Urban and Environmental Studies, Chinese Academy of Social Sciences (2013). China National Human Development Report. Sustainable and Liveable Cities: Toward Ecological Civilization. Beijing, China Translation and Publishing Corporation, 179 p. Available at: http://www.cn.undp.org/content/dam/ china/docs/Publications/UNDP-CH_2013\%20NHDR_EN.pdf (accessed 10 February 2019).

Veisi, H., Liaghati, H., Alipour, A. (2016). Developing an Ethics-Based Approach to Indicators of Sustainable Agriculture Using Analytic Hierarchy Process (AHP). In Ecological Indicators, 60, 644-654.

Walras, L. (2000). Elementy chistoi politicheskoi ekonomii (Éléments d'économie politique pure) [Elements of Pure Political Economy]. Moscow, Izograf, 448 p.

Wang, Y.J., Lee, H.S. (2007). Generalizing TOPSIS for Fuzzy Multiple-Criteria Group Decision-Making. In Computers and Mathematics with Applications, 53(11), 1762-1772. DOI: 10.1016/j.camwa.2006.08.037.

Wang, Y.M., Elhag, T.M. (2006). Fuzzy TOPSIS Method Based on Alpha Level Sets with an Application to Bridge Risk Assessment. In Expert Systems with Applications, 31, 309-319.

World Commission on Environment and Development (1987). Our Common Future. New York, Oxford University Press, 397 p. Available at: http://www.undocuments.net/our-common-future.pdf (accessed 10 February 2019).

Wursthorn, S., Poganietz, W.R., Schebek, L. (2011). Economic-Environmental Monitoring Indicators for European Countries: A Disaggregated Sector-Based Approach for Monitoring Eco-Efficiency. In Ecological Economics, 70, 487-496. DOI: 10.1016/j.ecolecon.2010.09.033.

Xu, C., Wang, S., Zhou, Y., Wang, L., Liu, W. (2016). A Comprehensive Quantitative Evaluation of New Sustainable Urbanization Level in 20 Chinese Urban Agglomerations. In Sustainability, 8, 91. DOI: 10.3390/su8020091.

Yin, K., Wang, R., An, Q., Yao, L., Liang, J. (2014). Using Eco-Efficiency as an Indicator for Sustainable Urban Development: A Case Study of Chinese Provincial Capital Cities. InEcological Indicators, 36, 665-671. DOI: 10.1016/j.ecolind.2013.09.003.

Zakharchuk, E.A, Pasynkov, A.F. (2008). Kontseptual'nye osnovy formirovaniia finansovoi ustoichivosti territorii: teoretiko-metodologicheskii podkhod [Conceptual Basis for the Formation of Financial Stability of a Territory: Theoretical and Methodological Approach]. In Ekonomika regiona [Economy of the Region], 4, $108-115$. 
Zhan, S.F., Zhang, X.C., Ma, C., Chen, W.P. (2012). Dynamic Modelling for Ecological and Economic Sustainability in a Rapid Urbanizing Region. In Procedia Environmental Sciences, 13, 242-251. DOI: 10.1016/j.proenv.2012.01.023.

Zhao, J., Chai, L. (2016). A Novel Approach for Assessing the Performance of Sustainable Urbanization Based on Structural Equation Modeling: A China Case Study. In Sustainability 8(9), 910. DOI: 10.3390/su8090910.

\title{
Инструменты оценки устойчивости развития территорий с учетом кластерных эффектов
}

\author{
И.С. Ферова, Е.В. Лобкова, \\ Е.Н. Таненкова, С.А. Козлова \\ Сибирский федеральный университет \\ Россия, 660041, Красноярск, пр. Свободный, 79
}

\begin{abstract}
Проблемы и поиски путей устойчивого развития территорий вызывают серьезную обеспокоенность органов власти во всем мире. Выбор методических подходов для оценки и мониторинга, показателей в качестве критериев устойчивости и способов их обработки является важной концептуальной основой, которая помогает эффективно содействовать развитию управляемых территорий.

Данное исследование направлено на поиск и анализ существующих подходов и инструментов мониторинга территориального развития, разработку собственной методологической и методической основы оценки устойчивости территорий в ичелях решения сочиально-экономических проблем. При этом основной концептуальнометодологической предпосылкой, отличающей предлагаемый подход, на наш взгляд, должен стать учет эффектов межрегионального, межотраслевого взаимодействия, или, по-другому, эффектов кластерных переливов. Выявлено, что среди авторов попрежнему отсутствует консенсус не только по теоретическим аспектам, но и по методологическим вопросам процедуры мониторинга и инструментам оценки устойчивости развития, особенно в контексте кластерного подхода.

В статье представлен анализ основных методологических подходов к оценке устойчивого развития систем различного уровня (национальной и региональной экономики, территорий, отраслей, предприятий, продуктов). Проведена систематизация подходов и инструментов, используемых учеными разных стран, международными организациями и институтами. Указаны преимущества, недостатки и ограничения практического применения выделенных методологических подходов. Изложена суть метода TOPSIS как инструмента оценки устойчивости развития территорий с учетом мультипликативных эффектов от межрегионального и межотраслевого взаимодействия. Показано, что именно кластерный подход является эффективным инструментом управления устойчивым развитием территориальных систем.
\end{abstract}


Ключевые слова: устойчивое развитие, территория, кластерный подход, метод TOPSIS, мониторинг, сочиально-экономические проблемы, инструменты оценки.

Исследование выполнено в рамках конкурса научных проектов междисциплинарных фундаментальных исследований, проводимого РФФИ совместно с Правительством Красноярского края, в 2018 г. Проект № 18-410-242005 р_мк «Разработка методики оиенки устойчивого развития территорий Красноярского края».

Научная специальность: 08.00 .00 - экономические науки. 